\title{
MONITORING OF POLYURETHANE DISPERSIONS AFTER THE SYNTHESIS
}

\author{
SPREMLJANJE POLIURETANSKIH DISPERZIJ PO SINTEZI
}

\author{
Martin Ocepek $^{\mathbf{1}}$, Jožefa Zabret ${ }^{1}$, Janez Kecelj ${ }^{1}$, Peter Venturini' ${ }^{2}$, Janvit Golob ${ }^{\mathbf{3}}$ \\ ${ }^{1}$ Helios TBLUS, d. o. o., Količevo 65, 1230 Domžale, Slovenia \\ ${ }^{2}$ Helios Domžale, d. d., Količevo 2,1230 Domžale, Slovenia \\ ${ }^{3}$ University of Ljubljana, Faculty of Chemistry and Chemical Technology, Aškerčeva cesta 5, 1000 Ljubljana, Slovenia \\ martin.ocepek@helios.si
}

Prejem rokopisa - received: 2014-06-05; sprejem za objavo - accepted for publication: 2014-09-30

\author{
doi:10.17222/mit.2014.086
}

\begin{abstract}
Chemical and physical parameters of the aqueous polyurethane dispersion (PUD) were studied after the synthesis. A prepolymer mixing process with a limited-chain extension step was used in order to examine the polymer and dispersion behavior with respect to the ageing time. Measurements of free isocyanate groups were performed with the aid of Fourier transform infrared spectroscopy (FT-IR). The pseudo-first-order kinetics of NCO disappearance was proposed and the value of the corresponding constant was determined. Additionally, particle size, particle size distribution, $\mathrm{pH}$, conductivity and molecular mass were monitored and compared.

Keywords: polyurethane dispersion, colloid, FT-IR

V raziskavi smo preučevali spreminjanje kemijskih in fizikalnih parametrov vodne poliuretanske disperzije (PUD) po sintezi. Disperzijo smo sintetizirali po postopku vmešavanja prepolimera $\mathrm{z}$ omejenim podaljševanjem verig za preučevanje polimerne disperzije z ozirom na čas po sintezi. Merjenje prostih izocianatnih skupin smo izvedli z metodo Fourierjeve transformacijske infrardeče spektroskopije (FT-IR). Predpostavili smo kinetični model psevdoprvega reda z ozirom na reakcije izocianatnih skupin ter določili vrednost kinetične konstante. Dodatno smo spremljali in primerjali povprečne velikosti delcev, porazdelitev velikosti delcev, $\mathrm{pH}$, prevodnost in molekulsko maso.

Ključne besede: poliuretanska disperzija, koloid, FT-IR
\end{abstract}

\section{INTRODUCTION}

Polyurethane dispersions (PUDs) are one of the options to replace conventional solvent-borne polyurethane materials for resins. The replacement is required by the directives of the European Union in order to use environmentally friendly and non-hazardous materials. ${ }^{1,2}$ The main advantages of PUD-based coatings are relatively good mechanical and chemical resistances, achieved only with physical drying at room temperature. However, these properties can be influenced using various polyols, isocyanates and their combinations with different ratios. The required high molecular mass is achieved with a chain extension with multifunctional amines. ${ }^{3-7}$

Many processes are used for a PUD preparation, although prepolymer mixing and acetone processes dominate in industrial applications. A prepolymer mixing process is mostly employed for the preparation of PUDs as coating binders. Using an acetone process, the PUDs for adhesives are synthesized. ${ }^{8-11}$ The prepolymer process can be subdivided. Firstly, a polymerization of diols and diisocyanates is performed in an organic solvent. Typically, N-methyl-2-pyrolidone (NMP) is used as it can efficiently dissolve the internal emulsifying monomer - 2.2-bis(hydroxymethyl)propionic acid (DMPA) and reduce the viscosity of the prepolymer. In a coating application NMP also serves as a coalescing agent, reducing the minimum film-forming temperature. ${ }^{11}$ Prior to dispersing, a neutralization of the pending carboxyl functional groups has to be performed in order to increase the hydrophilicity of the polymer chains. Afterwards, an isocyanate (NCO)-terminated prepolymer is dispersed in cold water, using high-shear forces. In the final stage, a water-soluble diamine is added as the chain extender to increase the molecular mass..$^{3,5-8,11-15}$ During all the stages of the synthesis numerous side reactions can occur due to the NCO reactivity. ${ }^{5,12,16}$

Due to the system complexity, where many principles are in place but only a few have an important influence on the final macroscopic material properties, this field of research is rather more of an industrial importance. ${ }^{17,18}$ In recent studies, the main focus was put on hardening two-component aqueous polyurethane coatings where the reactions and the mechanism itself are similar to those of a bulk PUD. However, the conditions (e.g., the water content) for coating hardening are significantly different. Consequently, the reported kinetic results are probably not applicable to dispersions.

Jang et al. ${ }^{14}$ found that the efficiency of the reaction of a chain extender with unreacted NCO groups regarding prepolymer chains is around $50 \%$ due to the limited diffusion of the chain-extender molecules into the core of the particles. Consequently, unreacted NCO groups 
Table 1: Relative reactivity of NCO group against different hydrogen-active compounds ${ }^{5,12}$

Tabela 1: Relativne reaktivnosti NCO-skupine $\mathrm{z}$ različno aktivnimi vodikovimi spojinami ${ }^{5,12}$

\begin{tabular}{|c|c|c|c|}
\hline Functional group & Formula & Relative reaction rate & Linkage \\
\hline Primary aliphatic amine & $\mathrm{R}-\mathrm{NH}_{2}$ & 2500 & Urea \\
\hline Secondary aliphatic amine & $\mathrm{R}_{2}-\mathrm{NH}$ & $500-1250$ & Urea \\
\hline Primary hydroxyl & $\mathrm{R}-\mathrm{CH}_{2}-\mathrm{OH}$ & 2.5 & Urethane \\
\hline Water & $\mathrm{HOH}$ & 2.5 & Urea \\
\hline Carboxylic acid (non-dissociated) & $\mathrm{R}-\mathrm{COOH}$ & 1 & Amide, $\left(+\mathrm{CO}_{2}(\mathrm{~g})\right)$ \\
\hline Secondary hydroxyl & $\mathrm{R}_{2}-\mathrm{CH}-\mathrm{OH}$ & 0.75 & Urethane \\
\hline Urea & R-NH-CO-NH-R & 0.375 & Biuret \\
\hline 20Urethane & R-NH-COOR & 0.0025 & Allophanate \\
\hline
\end{tabular}

stay buried inside the particles. However, this thesis was only confirmed with the measurements of the molecular mass. In another study ${ }^{4}$ researchers showed that only 60 $\%$ of the theoretical amount of diamine is sufficient to achieve a NCO conversion below the FT-IR detection. The reported results seem somehow contradictory. However, differences might be attributed to polyol selection and synthesis parameters or the reported results might have been influenced by the characterization methods.

From the engineering point of view, NCO conversion kinetics is at least of the same importance as the NCO thermodynamic background. The relative reactivity of isocyanate with hydrogen-active compounds can be found in Table 1. According to these data, one can assume that the disappearance of unreacted NCO groups (after an amine-chain extension reaction) is mainly due to the reaction with water. Figure 1 presents a possible mechanism. The main products are urea linkages and gaseous $\mathrm{CO}_{2}$. Additionally, some biuret formation is expected. ${ }^{19}$ The reaction with carboxylic groups is retarded due to a steric hindrance and a dissociation. ${ }^{5}$

The widely used dibutylamine back-titration $\operatorname{method}^{7}$ was found inappropriate for the measurements of the residual NCO groups since high amounts of amine and water are involved. Therefore, those data were obtained by means of FT-IR spectroscopy, which represents a powerful tool to monitor NCO groups in an aqueous environment. ${ }^{4,5,9,10,20}$ A conversion of the NCO groups was obtained through integrated absorbance-peak areas: $^{21-24}$

$$
\int A(\widetilde{v}) d \widetilde{v}=b c \int a(\widetilde{v}) d \widetilde{v}=b c A
$$

where $A(\widetilde{v})$ stands for the absorbance at a specific wavenumber $\left(\mathrm{cm}^{-1}\right), a(\widetilde{v})\left(\mathrm{L} \mathrm{mol}^{-1} \mathrm{~cm}^{-1}=0.1 \mathrm{~m}^{2} \mathrm{~mol}^{-1}\right)$ is

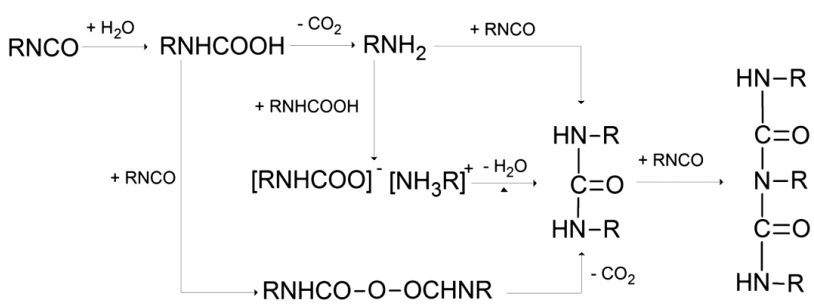

Figure 1: Reaction mechanism of isocyanate with water ${ }^{19}$ Slika 1: Mehanizem reakcije izocianatne skupine $\mathrm{z}$ vodo ${ }^{19}$ the molar absorption coefficient, specific for a particular functional group at a specific wavelength, $b(\mathrm{~cm})$ is the path length through the sample, $c\left(\mathrm{~mol} \mathrm{~L}^{-1}\right)$ represents the molar concentration and $A\left(\mathrm{~L} \mathrm{~mol}^{-1} \mathrm{~cm}^{2}\right)$ represent the integrated absorption coefficient.

The purpose of this research is to monitor the reaction between water and prepolymer terminal NCO groups. The reaction kinetics is studied using Fourier transform infrared spectroscopy. For this purpose, only $50 \%$ of the theoretical amount of bifunctional amine is used in the chain-extension step. Simultaneously, important physico-chemical parameters of the dispersion is measured and evaluated through particle size, particle size distribution, $\mathrm{pH}$, conductivity and relative molecular mass.

\section{EXPERIMENTAL WORK}

\subsection{Materials}

An ester-type polyol was previously prepared via a condensation polymerization from a technical grade including 1.6 hexanediol, adipic and isophthalic acid (Table 2). A linear macrodiol was proposed as only bi-functional monomers were used. The starting hydroxyl-to-carboxyl molar ratio was chosen to be 1.15 in order to ensure hydroxyl-terminated chains. The measured hydroxyl number of $57 \mathrm{mg} \mathrm{KOH} \mathrm{g}^{-1}$ corresponds to the average molecular mass of $2000 \mathrm{~g} \mathrm{~mol}^{-1}$ at the acid number of $0.6 \mathrm{mg} \mathrm{KOH} \mathrm{g}^{-1}$. The water content was below mass fraction $0.05 \%$. Polyester was melted and maintained at $50{ }^{\circ} \mathrm{C}$ for $6 \mathrm{~h}$ before use.

Table 2: Formulation for polyol synthesis and its properties Tabela 2: Receptura za sintezo poliola in njegove lastnosti

\begin{tabular}{|l|c|c|}
\hline \multicolumn{1}{|c|}{ Component } & $\mathrm{m} / \mathrm{g}$ & $\mathrm{n} / \mathrm{mol}$ \\
\hline 1.6 Hexanediol & 236.91 & 2.004 \\
\hline Adipic acid & 183.70 & 1.257 \\
\hline Isophthalic acid & 79.09 & 0.486 \\
\hline Properties & \\
\hline hydroxyl number & $(57 \pm 1) \mathrm{mg} \mathrm{KOH} \mathrm{g}^{-1}$ \\
\hline acid number & $(0.6 \pm 0.1) \mathrm{mg} \mathrm{KOH} \mathrm{g}^{-1}$ \\
\hline$M_{\mathrm{n}}$ (titrimetric) & $(2000 \pm 50) \mathrm{g} / \mathrm{mol}^{\circ}$ \\
\hline$T_{\mathrm{g}}$ & \multicolumn{2}{|c|}{$(-53 \pm 1){ }^{\circ} \mathrm{C}$} \\
\hline$T_{\mathrm{m}}$ & $(25 \pm 1){ }^{\circ} \mathrm{C}$ \\
\hline
\end{tabular}


Isophorone diisocyanate (IPDI; Evonik Degussa), 2.2-bis(hydroxymethyl)propionic acid (DMPA; Perstorp), dibutyltin dilaurate (DBTDL; Air Products), all of a technical grade, N-methyl-2-pyrrolidone (NMP; Acros Organics), triethyamine (TEA; J.T. Baker) and isophoronediamine (IPDA; BASF), all of a laboratory grade, were used. Deionized water had the conductivity below 20 $\mu \mathrm{S} \mathrm{cm} \mathrm{cm}^{-1}$.

\subsection{PUD synthesis}

The formulation can be found in Table 3. The polymerization was carried in round-bottom $1 \mathrm{~L}$, four-necked flask with a mechanical stirrer, condenser and digital thermometer connected to an automatically controlled electric-heating mantel. The system was kept in a nitrogen atmosphere during the whole synthesis process. At first, NMP, DMPA and the melted polyester polyol were put into the reactor and stirred at $30{ }^{\circ} \mathrm{C}$ for $10 \mathrm{~min}$ to achieve homogenization. Afterwards, a mixture of IPDI and catalyst DBTDL was shot-added. After additional $5 \mathrm{~min}$ of homogenization, the first sample was taken out in order to verify the starting mass fraction of NCO groups. The di- $n$-dibutylamine back-titration method $^{7}$ was used. The mixture in the reactor was then heated up to $82{ }^{\circ} \mathrm{C}$ in $30 \mathrm{~min}$ and maintained there for another hour, followed by cooling down to $65^{\circ} \mathrm{C}$. The residual amount of $\mathrm{NCO}$ was determined before an equimolar amount of TEA (with respect to DMPA carboxyl groups) was shot-added. After 15 min of homogenization, a neutralized polymer was introduced into a double-jacketed dispersion vessel $2 \mathrm{~L}$ in a period of 10 min. High shear forces were applied during this time,

Table 3: Formulation for PU prepolymer synthesis and its properties Tabela 3: Receptura za sintezo PU-prepolimera in njegove lastnosti

\begin{tabular}{|c|c|c|}
\hline Component & $m / \mathrm{g}$ & $n / \mathrm{mol}$ \\
\hline NMP & 100.0 & 1.009 \\
\cline { 2 - 3 } DMPA & 14.50 & 0.108 \\
\hline Polyester polyol (Table 2) & 137.90 & 0.078 \\
\hline DBTDL & 0.50 & $7.9 \cdot 10^{-4}$ \\
\hline IPDI & 78.80 & 0.355 \\
\hline TEA & 10.7 & 0.108 \\
\hline \multicolumn{2}{|c|}{ Properties } \\
\hline residual free $w(\mathrm{NCO}){ }^{*}$ & $(4540 \pm 100) \mathrm{g} / \mathrm{mol}$ \\
\hline$M_{\mathrm{n}}(\mathrm{SEC})$ & $(7060 \pm 100) \mathrm{g} / \mathrm{mol}$ \\
\hline$M_{\mathrm{w}}(\mathrm{SEC})$ & $1.56 \pm 0.02$ \\
\hline$M_{\mathrm{w}} / M_{\mathrm{n}}$ &
\end{tabular}

$* w$ (mass fraction)

Table 4: Recipe for dispersing and chain-extension steps Tabela 4: Receptura za dispergiranje in podaljševanje verig

\begin{tabular}{|l|c|c|}
\hline Component & $\mathrm{m} / \mathrm{g}$ & $n / \mathrm{mol}$ \\
\hline PU prepolymer & 298.0 & 0.130 \\
\hline BYK 093 (antifoaming additive) & 1.0 & N/A \\
\hline IPDA & 11.1 & 0.065 \\
\hline Water for IPDA & 50.0 & 2.778 \\
\hline
\end{tabular}

using a dissolver-disc stirrer with a diameter of $7 \mathrm{~cm}$ at $1800 \mathrm{r} / \mathrm{min}$. A few drops of commercially available anti-foaming additive were used. Preliminary, the water in the double-jacketed dispersion vessel was cooled below $20{ }^{\circ} \mathrm{C}$ and maintained at this temperature to the end of the process. Ten minutes after the end of dispersion, a pre-prepared IPDA-water mixture (Table 4) was added dropwise in a period of $30 \mathrm{~min}$. The stirring was reduced to $1000 \mathrm{r} / \mathrm{min}$. The end of the chainextender addition was defined as the end of the synthesis, presenting time zero for the ageing study. After the synthesis, PUD was poured into a plastic container $1 \mathrm{~L}$ and kept at a temperature of $(20 \pm 1){ }^{\circ} \mathrm{C}$ throughout the ageing study process. The container was sealed all the time, except when the samples were taken out.

\subsection{Characterization}

FT-IR spectra were measured with a Nicolet 6700 spectrophotometer, manufactured by Thermo Scientific. The samples were handled manually on a zinc-selenide (ZnSe) pellet. Care was taken that all the samples had the maximum absorbance-peak height (the ester peak) close to 1 since this parameter is defined as the condition for the most accurate quantitative measurement. The error was estimated to be below $10 \%$ in this case. ${ }^{20,22}$ The spectra at wavenumbers between $650 \mathrm{~cm}^{-1}$ and 4000 $\mathrm{cm}^{-1}$, with a resolution of $4 \mathrm{~cm}^{-1}$, were taken. The areas of the NCO peaks between $2170 \mathrm{~cm}^{-1}$ and $2330 \mathrm{~cm}^{-1}$ were normalized to the unchanging areas under the $\mathrm{CH}$ peaks at wavenumbers of $2820-3010 \mathrm{~cm}^{-1}$. The instrument software was used for this purpose. Molecular mass averages $\left(M_{\mathrm{w}}, M_{\mathrm{n}}\right)$ and their distributions $\left(M_{\mathrm{w}} / M_{\mathrm{n}}\right)$, relative to the polystyrene standards, were determined with size-exclusion chromatography (SEC) on an Agilent 1260 Infinity liquid chromatograph (Agilent Technologies) with a differential refractive-index detector at 35 ${ }^{\circ} \mathrm{C}$. The analyses were performed on a single pore-sized Phenogel linear column $5 \mathrm{~mm}(300 \mathrm{~mm} \times 7.8 \mathrm{~mm})$ with a styrene-divinylbenzene copolymer column packing. Tetrahydrofuran (THF) was used as an eluent with a flow rate of $1.0 \mathrm{~mL} \mathrm{~min}^{-1}$. The samples were prepared in solutions and allowed to dissolve for three days. Prior to the analysis, the samples were filtered through a PTFE filter $0.45 \mathrm{~mm} .100 \mu \mathrm{L}$ of the prepared sample was injected into the column.

The conductivity and $\mathrm{pH}$ were measured without any sample preparation using a SevenMulti $\mathrm{pH}$ meter (Mettler Toledo). The $\mathrm{pH}$ electrode was calibrated using the standard buffer solutions (4.01, 7.00 and 10.01). The conductivity cell was calibrated using the standard electrolyte solution with $1.413 \mathrm{mS} \mathrm{cm}^{-1}$ at $25^{\circ} \mathrm{C}$. Particle sizes were measured employing the dynamic light scattering (DLS) method at a scattering angle of $173^{\circ}$. A ZetaSizer (ZS) nano series, manufactured by Malvern, was used for these purposes. The samples were diluted in DI water to approximately volume fraction $0.1 \%$ and poured into a proper cell. The $\mathrm{Z}$-average ${ }^{25}$ was obtained 
using the Malvern software. Glass transition temperatures $\left(T_{\mathrm{g}}\right)$ were determined with the differential scanning calorimeter (DSC) 1 STAR system (Mettler Toledo). The heat flow was measured under a heat rate of $10 \mathrm{~K} \mathrm{~min}^{-1}$ in a range from $-70{ }^{\circ} \mathrm{C}$ to $120^{\circ} \mathrm{C}$. The total solid content was determined gravimetrically, after $1 \mathrm{~h}$ at $125^{\circ} \mathrm{C}$. The hydroxyl number was determined according to ASTM D 1957.

\section{RESULTS AND DISCUSSION}

The primary objective of this study was to track PUD properties with respect to the ageing time. According to the isocyanate reactivity, a reaction with water molecules is expected. ${ }^{15,19}$ While solvent-borne PU polymers can be easily dissolved and analyzed with advanced methods (e.g., nuclear magnetic resonance), ${ }^{9,26}$ a PUD analysis is limited due to a poor solubility of cross-linked and branched polymer chains. Colloidal physical parameters (e.g., particle size, particle size distribution, $\mathrm{pH}$, conductivity) become of a greater importance in a PUD characterization. Nevertheless, the chemical changes can be monitored with FT-IR. ${ }^{4-14,21,26,27}$

\subsection{PUD design and properties}

Table 3 consists of the formulation and properties of the PU prepolymer before being dispersed. There is no doubt that PUD colloidal features depend upon the PU prepolymer. Among these features, the molecular mass, the DMPA content and its degree of neutralization might be the most important. ${ }^{14}$ For the purpose of this investigation, the mass fraction $6.4 \%$ of DMPA was used, based on the total prepolymer solids. $100 \%$ neutralization was carried out by means of TEA as this compound was reported to be the most efficient. ${ }^{14}$

The PUD final properties can be found in Table 5. The DSC curves of polyester polyol and the final PUD in Figure 2 prove that polyol was successfully polymerized since no melting-temperature-transition $\left(T_{\mathrm{m}}\right)$ peak was detected for the PUD sample. $T_{\mathrm{g}}$ of polyol and PUD are practically identical at $(-53 \pm 1)^{\circ} \mathrm{C}$. The latter represents the 'soft' phase and, consequently, this PUD can be classified as a rubber-like elastomeric material at room temperature. ${ }^{12}$ In general, PUs have another $T_{\mathrm{g}}$ at higher

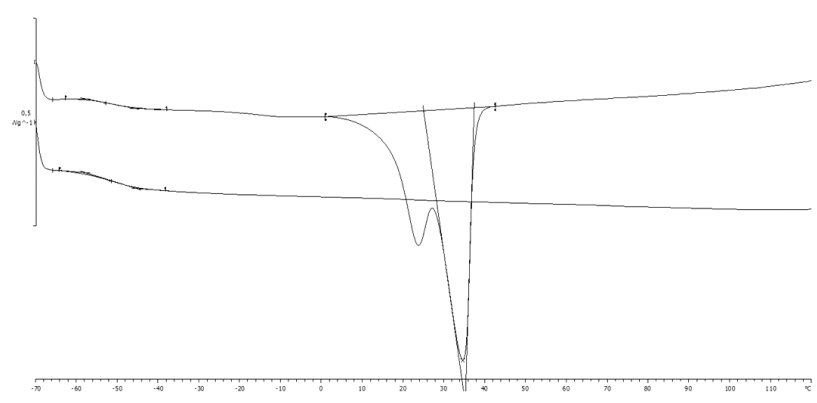

Figure 2: DSC curves (top - polyester polyol, bottom - final PUD) Slika 2: DSC-krivulji (zgoraj - poliestrski poliol, spodaj - končna PUD) temperatures, representing the 'hard' phase. ${ }^{12}$ However, the second $T_{\mathrm{g}}$ was not detected on the PUD sample. That might have been due to a higher $\mathrm{NCO} / \mathrm{OH}$ ratio, resulting in pronounced amounts of hydrogen bonds, ${ }^{28}$ severe crosslinking and branching, which all contribute to raising the second $T_{\mathrm{g}}$ above the measured conditions. ${ }^{12}$

Table 5: PUD final properties

Tabela 5: Končne lastnosti PUD

\begin{tabular}{|c|c|c|}
\hline & Parameter & Value \\
\hline \multirow{4}{*}{ Final PUD } & total solids, $w / \%$ & 33.3 \\
\cline { 2 - 3 } & soft phase $T_{\mathrm{g}}$ & $(-53 \pm 1){ }^{\circ} \mathrm{C}$ \\
\cline { 2 - 3 } & hard phase $T_{\mathrm{g}}$ & not detected \\
\hline
\end{tabular}

The NCO-terminated prepolymer had $4540 \mathrm{~g} \mathrm{~mol}^{-1}$ of $M_{\mathrm{n}}$ according to SEC and $1580 \mathrm{~g} \mathrm{~mol}^{-1}$ of $M_{\mathrm{g}}$ calculated from $\% \mathrm{NCO}$, assuming the ideal bifunctional NCO-terminated prepolymer. The almost three times higher $M_{\mathrm{n}}$ amount from SEC is somehow expected due to the formation of allophanate, resulting in some crosslinking. ${ }^{5,7}$ The authors agree that the SEC result should be considered as the most reliable.

\subsection{FT-IR spectra evaluation and the kinetic model}

In the cases where constant $a b$ can be determined via calibration curves, the expression of concentration is trivial. However, this is not the case in this study. The path length $(b)$ is not constant due to the manual handling of a sample on the glass pellet. To avoid this variable, integrated absorbances under the NCO peaks were normalized to the $\mathrm{CH}$ peak, which is assumed to remain unchanged during the ageing. As a result, relative integrated absorbances were obtained. It was also assumed that absorption coefficients $(\alpha)$ did not significantly change during the monitoring. From the absorbance areas, the conversion of the NCO groups can be directly determined using: ${ }^{21}$

$$
\alpha=\left[1-\frac{\left(A_{\mathrm{NCO}} / A_{\mathrm{CH}}\right)_{t}}{\left(A_{\mathrm{NCO}} / A_{\mathrm{CH}}\right)_{t=0}}\right] \cdot 100
$$

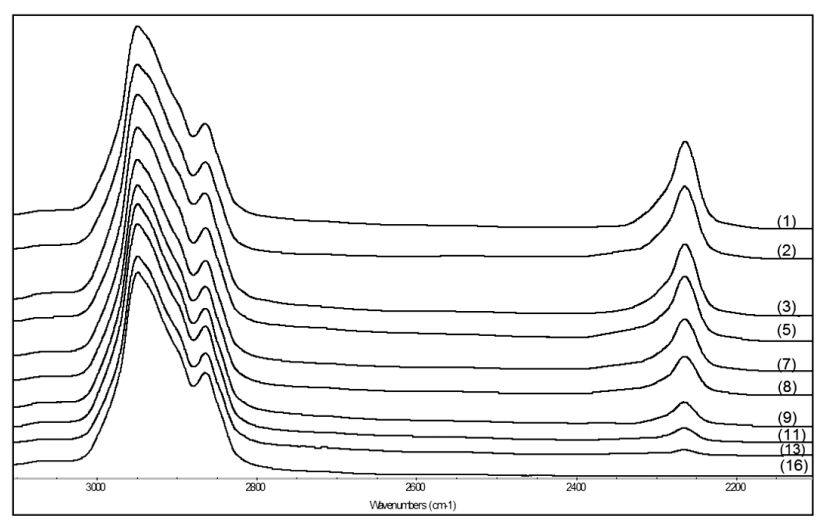

Figure 3: Selected FT-IR spectra of the observed PUD after the synthesis. For sample indices see Table 6.

Slika 3: Izbrani FT-IR-spektri PUD v času po sintezi. Oznake vzorcev se navezujejo na tabelo 6. 


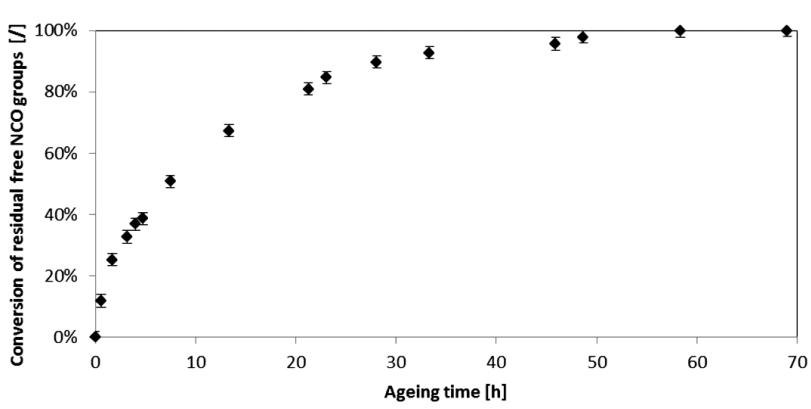

Figure 4: Conversion of residual free NCO groups after the synthesis Slika 4: Pretvorba prostih NCO-skupin po sintezi

where $\alpha$ is the $\mathrm{NCO}$ conversion $(\%),\left(A_{\mathrm{NCO}} / A_{\mathrm{CH}}\right)_{\mathrm{t}=0}$ is the relative integrated absorbance area at the ageing start and $\left(A_{\mathrm{NCO}} / A_{\mathrm{CH}}\right)_{\mathrm{t}}$ is the relative integrated absorbance area at the specific time $t$. Using the proposed model, the standard calibration curve is not needed. That is especially true for the first-order kinetics where the starting concentration is not needed to obtain a conversion. ${ }^{23}$ Another advantage of this approach is the elimination of the errors resulting from the water and NMP evaporation.

The selected FT-IR spectra in a period of three days after the synthesis are presented in Figure 3. The normalized area of Sample 1 (time 0) was taken as the starting point. The obtained results can be seen in Figure 4. The integrated areas and the associated conversions calculated using Equation (2) can be found in Table 6. For the purpose of determining the kinetic order, logarithms of the normalized areas were calculated and are presented in Figure 5. $90 \%$ of the NCO conversion was detected after $33 \mathrm{~h}$. In comparison with the previous study, ${ }^{17}$ the NCO consumption in this study case is faster. The authors believe that the unlimited availability of water molecules is responsible for such a behavior. The

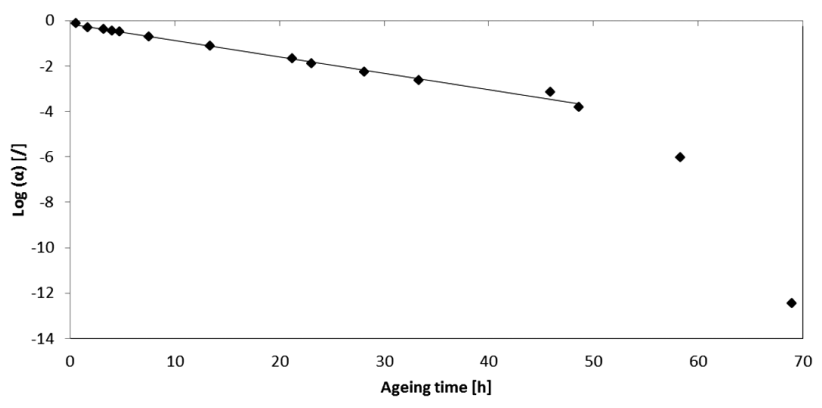

Figure 5: Conversion logarithm of residual NCO groups Slika 5: Logaritem pretvorbe prostih NCO-skupin

quantity below the FT-IR detection limit was achieved after 2.5-3 d. According to the data points in Figure 5, one might conclude that the first-order kinetic model does not fit. However, ignoring the last two points resulting from the FT-IR inaccuracy at very high conversions, the fitting line with a slope of $-0.077 \mathrm{~h}^{-1}$ and a rootmean-square deviation (RMSD) of 0.984 can be used to describe the data. Furthermore, neglecting the first point, a slope of $-0.072 \mathrm{~h}^{-1}$ with $R M S D$ of 0.991 can be obtained. This fitting accuracy permits us to assume the first-order or at least the pseudo-first-order kinetics behavior. This is not in agreement with the reported second order at the beginning and the third order at higher conversions when the ratio of $\mathrm{NCO}$ to water $\mathrm{OH}$ was $1: 1^{21}$. Again, the continuous water environment in PUDs governs the residual NCO group-reaction kinetics. To some extent, water diffusion can retard the reaction; however, this becomes significant only at a high conversion.

\subsection{Molecular mass}

The trend of the increasing molecular mass is visible from the SEC curve comparison in Figure 6. The

Table 6: Ageing-measurement data

Tabela 6: Podatki meritev staranja

\begin{tabular}{|c|c|c|c|c|c|c|c|c|c|c|c|}
\hline$\#$ & time $(\mathrm{h})$ & $A_{\mathrm{NCO}}$ & $A_{\mathrm{CH}}$ & $A_{\mathrm{NCO}} / A_{\mathrm{CH}}$ & $\alpha / \%$ & $\mathrm{LN}\left(A_{\mathrm{NCO}} / A_{\mathrm{CH}}\right)$ & $\mathrm{pH}$ & $\begin{array}{c}\text { conductivity } \\
(\mathrm{mS} / \mathrm{cm})\end{array}$ & $D_{\mathrm{z}} / \mathrm{nm}$ & $M_{\mathrm{n}} /(\mathrm{g} / \mathrm{mol})$ & $M_{\mathrm{w}} /(\mathrm{g} / \mathrm{mol})$ \\
\hline 1 & 0 & 5.21 & 20.58 & 0.253 & 0 & 0 & 8.07 & - & 88 & 5.710 & 10.110 \\
\hline 2 & 0.583 & 5.65 & 25.33 & 0.223 & 11.9 & -0.127 & 7.67 & 1.31 & 90 & - & - \\
\hline 3 & 1.70 & 2.75 & 14.55 & 0.189 & 25.3 & -0.292 & 7.55 & 1.39 & 92 & - & - \\
\hline 4 & 3.17 & 7.61 & 44.70 & 0.170 & 32.8 & -0.397 & 7.24 & 1.46 & 89 & - & - \\
\hline 5 & 4.00 & 7.67 & 48.02 & 0.160 & 36.9 & -0.461 & 7.22 & 1.50 & 89 & - & - \\
\hline 6 & 4.75 & 3.47 & 22.38 & 0.155 & 38.8 & -0.490 & 7.19 & 1.52 & 88 & - & - \\
\hline 7 & 7.50 & 7.23 & 58.06 & 0.125 & 50.8 & -0.709 & 7.10 & 1.58 & 90 & 11.410 & 25.410 \\
\hline 8 & 13.3 & 8.32 & 100.7 & 0.083 & 67.4 & -1.12 & 7.00 & 1.64 & 87 & - & - \\
\hline 9 & 21.3 & 1.58 & 32.73 & 0.048 & 80.9 & -1.66 & 6.97 & 1.68 & 89 & 13.490 & 30.670 \\
\hline 10 & 23.1 & 1.13 & 29.10 & 0.039 & 84.7 & -1.87 & 6.95 & 1.69 & 88 & - & - \\
\hline 11 & 28.1 & 1.09 & 42.00 & 0.026 & 89.7 & -2.28 & 6.98 & 1.67 & 88 & - & - \\
\hline 12 & 33.3 & 1.11 & 60.54 & 0.018 & 92.8 & -2.63 & 6.99 & 1.67 & 86 & - & - \\
\hline 13 & 45.9 & 0.18 & 16.49 & 0.011 & 95.7 & -3.14 & 6.98 & 1.68 & 87 & - & - \\
\hline 14 & 48.7 & 0.081 & 14.66 & 0.006 & 97.8 & -3.82 & 6.97 & 1.67 & 90 & - & - \\
\hline 15 & 58.3 & 0.02 & 33.19 & 0.001 & $99.8 *$ & -6.04 & 6.98 & 1.67 & 88 & - & - \\
\hline 16 & 69.0 & 0 & 18.53 & 0.000 & $100.0 *$ & -12.44 & 6.97 & 1.68 & 90 & 21.560 & 64.540 \\
\hline
\end{tabular}




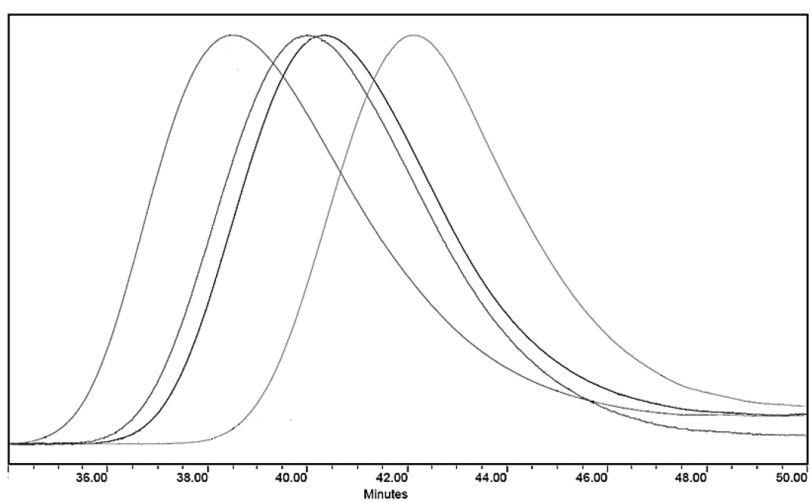

Figure 6: SEC results (from right to left: samples 1, 7, 9, 16) Slika 6: SEC-rezultati (od leve proti desni: vzorci 1, 7, 9, 16)

average molecular mass according to the polystyrene standards are presented in Table 6. The molecular mass is increasing during the ageing, as can be expected due to the formation of urea linkages, which are formed after the reaction between NCO and water., ${ }^{3,5,6,8,11-17}$ The $M_{\mathrm{w}} / M_{\mathrm{n}}$ ratio also increases from the initial 1.77 to 2.99 at the end. Nevertheless, the molecular mass distribution remains relatively narrow, indicating that the chain extension is relatively uniform. It is important to note that there were some problems with the sample solubility in THF, which was pronounced with the increasing molecular mass. Insoluble parts were filtered out. Consequently, those results should be taken with a reserve and can only serve as a relative comparison between the samples.

\section{$3.4 \mathrm{pH}$ and conductivity}

Figure 7 shows the $\mathrm{pH}$ and conductivity changes during the ageing process. It can be seen that $\mathrm{pH}$ is decreasing to the $67 \%$ conversion, followed by a constant value afterwards. As reported ${ }^{17,18}$, the $\mathrm{pH}$ drop is attributed to the formation of carbon acid from $\mathrm{CO}_{2}$ which is a side product of the NCO reaction with water. ${ }^{3,5,7,15-18} \mathrm{~A}$ $\mathrm{pH}$ of $(7.00 \pm 0.05)$ seems to be the equilibrium value in this system and is close to the reported value of $6.9 .{ }^{17}$ Due to the fact that new ions are formed, it is quite clear

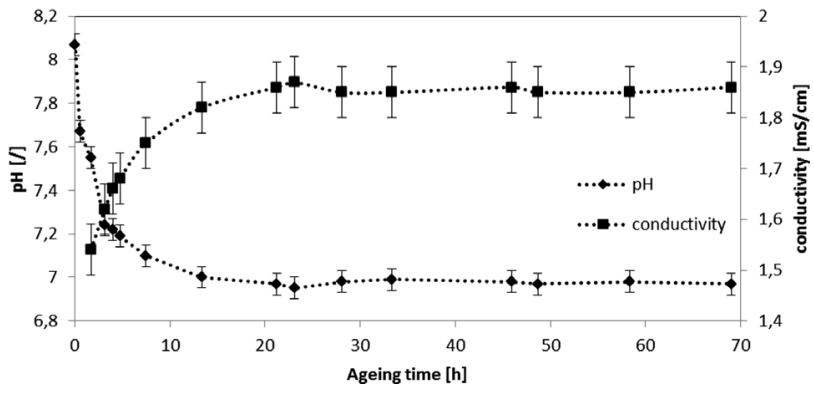

Figure 7: pH and conductivity changes during ageing. Dotted line is only drawn as a guide for the eye.

Slika 7: Spremembe $\mathrm{pH}$ in prevodnosti med staranjem. Prekinjena črta je narisana zgolj za lažje spremljanje.

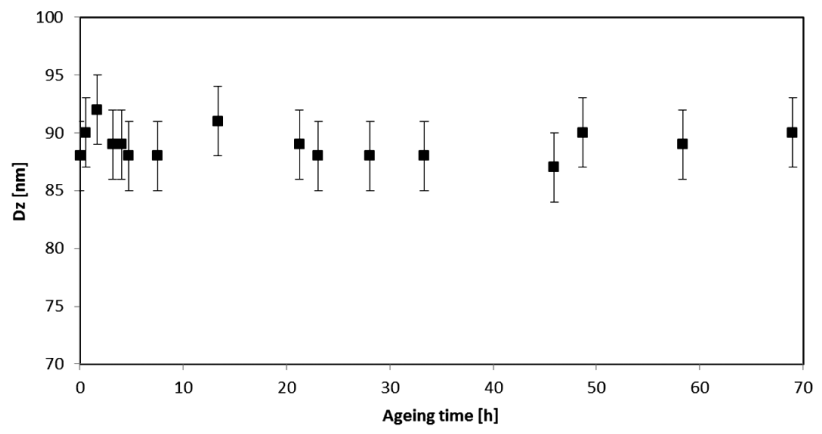

Figure 8: Average particle-size diameter $\left(D_{\mathrm{z}}\right)$ during ageing Slika 8: Povprečne velikosti delcev $\left(D_{\mathrm{z}}\right)$ med staranjem

that the conductivity increase is practically a mirror image of the $\mathrm{pH}$ curve. It has to be noted that a reliable conductivity measurement of the first sample was prevented by the air bubbles generated during the dispersing step.

\subsection{Particle size}

Figures 8 and 9 reveal that the average particle size $\left(D_{\mathrm{z}}\right)$ and particle size distribution did not significantly change during the ageing. Additionally, the DLS polydispersity index was below 0.1 in all the cases, meaning
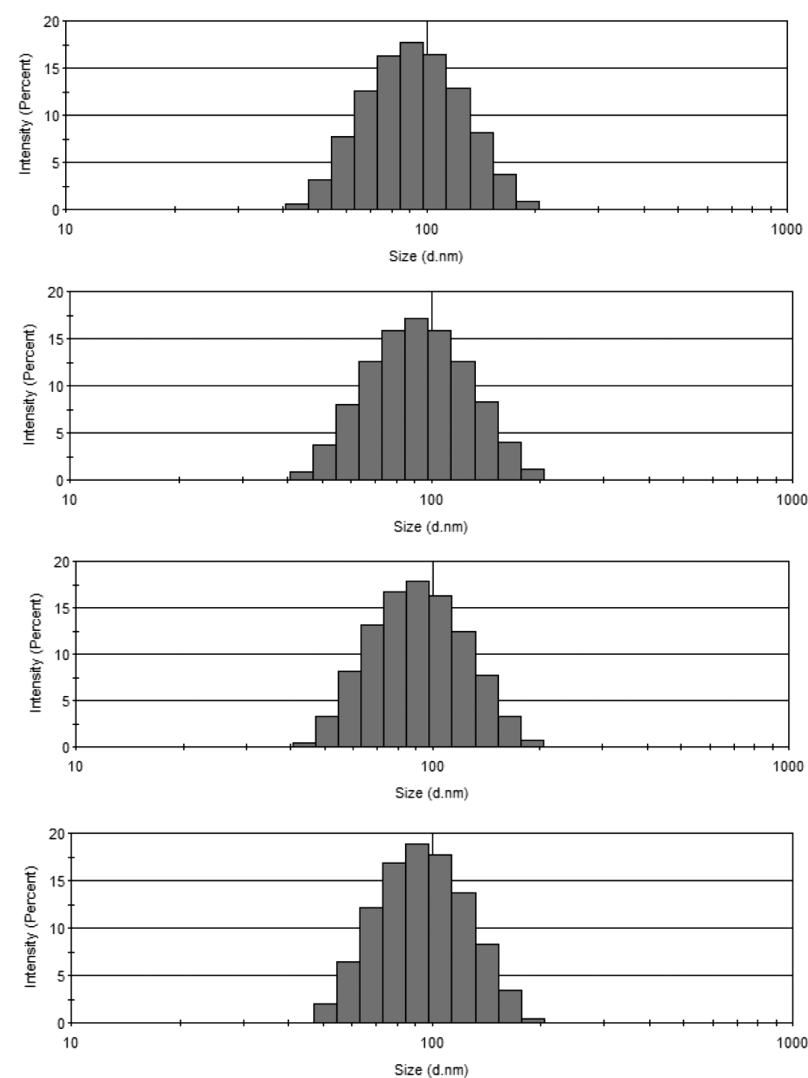

Figure 9: Selected DLS particle size distribution (from top to bottom: samples $1,6,13,16$ )

Slika 9: Izbrani DLS-spektri porazdelitve velikosti delcev (od zgoraj navzdol: vzorci $1,6,13,16)$ 
that PUD can be considered to be monodisperse. ${ }^{26}$ The same polydispersity (within a range $30 \mathrm{~nm}$ ) was observed for all the samples. This result was expected since intra-particle events do not significantly influence the particle size. However, when the electrochemical or steric stability is affected, a particle agglomeration leads to bigger particles. ${ }^{5,25}$

\section{CONCLUSIONS}

PUDs are probably the best option to replace solvent-borne polyurethanes where health risks must be decreased. Even though they have been known for decades, the final coating, or the adhesive quality, is seldom the same. This can be mostly attributed to the water's unique properties which transform a polymer solution into a colloidal dispersion. After the PUD synthesis, FT-IR spectroscopy detected a $85 \%$ conversion of the residual NCO groups after one day, and a full conversion after $2.5-3 \mathrm{~d}$. The data obtained was well described using a pseudo-first-order kinetic model. The kinetic constant was found to be $(0.077 \pm 0.005) \mathrm{h}^{-1}$. The colloid perspective confirmed the expected $\mathrm{pH}$ drop and the resulting conductivity increase. The average particle size and particle size distribution stayed unchanged, confirming that an increased molecular mass does not influence the colloidal particle size.

\section{Acknowledgements}

This operation was partly financed by the European Union, European Social Fund. The operation was carried out in the framework of the Operational Program for Human Resources Development for the Period 2007-2013, Priority axis 1: Promoting entrepreneurship and adaptability, Main type of activity 1.3: Scholarship scheme (contract No. 62231-268).

\section{REFERENCES}

${ }^{1}$ Council of the European Union, Solvent Emissions Directive 1999/13/EC, Official Journal of the European Union, L 085 (1999), $1-22$

${ }^{2}$ European Parliament, Council of the European Union, Paints Directive 2004/42/CE, Official Journal of the European Union, L 143 (2004), 87-96

${ }^{3}$ B. K. Kim, Colloid Polym. Sci., 274 (1996), 599-611, doi:10.1007/ BF00653056

${ }^{4}$ Y. K. Jhon, I. W. Cheong, J. H. Kim, Colloids and Surfaces A: Physicochem. Eng. Aspects, 179 (2001), 71-78, doi:10.1016/S09277757(00)00714-7
${ }^{5}$ Z. Wicks, F. Jones, S. P. Pappas, Organic Coatings: Science and Technology, third ed., John Wiley and Sons, New York 2007, doi:10.1002/047007907X

${ }^{6}$ O. Jaudouin, J. J. Robin, J. M. Lopez-Cuesta, D. Perrin, C. Imbert, Poly. Int., 61 (2012) 4, 495-510, doi:10.1002/pi.4156

${ }^{7}$ G. Oertel, Polyurethane handbook, Hanser Publishers, Munich 1985

${ }^{8}$ S. A. Madbouly, J. U. Otaigbe, Prog. Poly. Sci., 34 (2009), 1283-1332, doi:10.1016/j.progpolymsci.2009.08.002

${ }^{9}$ H. Sardon, L. Irusta, M. J. Fernandez-Berridi, J. Luna, M. Lansalot, E. Bourgeat-Lami, J. Appl. Polym. Sci., 120 (2011), 2054-2062, doi:10.1002/app.33308

${ }^{10}$ H. Sardon, L. Irusta, M. J. Fernández-Berridi, Prog. Org. Coat., 66 (2009), 291-295, doi:10.1016/j.porgcoat.2009.08.005

${ }^{11}$ K. Noll, W. Thoma, K. Nachtkamp, W. Schroer, J. Pedain, US Patent No. 4876302, 1989

${ }^{12}$ D. K. Chattopadhyay, K. V. S. N. Raju, Prog. Polym. Sci., 32 (2007), 352-418, doi:10.1016/j.progpolymsci.2006.05.003

${ }^{13}$ G. A. Howarth, Surf. Coating Int. B: Coating Trans., 86 (2003), 111-118, doi:10.1007/BF02699621

${ }^{14}$ J. Y. Jang, Y. K. Jhon, I. W. Cheong, J. H. Kim, Colloids and Surfaces A: Physicochem. Eng. Aspects, 196 (2002), 135-143, doi:10.1016/S0927-7757(01)00857-3

${ }^{15}$ M. Ionescu, Chemistry and Technology of Polyols for Polyurethanes, Rapra Technology, Shropshire 2005

${ }^{16}$ U. Meier-Westhues, Polyurethanes Coatings, Adhesives and Sealants, Vincentz Network, Hannover 2007

${ }^{17}$ M. Melchiors, M. Sonntag, C. Kobusch, E. Jurgens, Prog. Org. Coat., 40 (2000), 99-109, doi:10.1016/S0300-9440(00)00123-5

${ }^{18}$ W. Collong, A. Gobel, B. Kleuser, W. Lenhard, M. Sonntag, Prog. Org. Coat., 45 (2002), 205-209, doi:10.1016/S0300-9440(02) 00052-8

${ }^{19}$ G. Shkapenko, G. T. Gmitter, E. E. Gruber, Ind. Eng. Chem., 52 (1960) 7, 605-608, doi:10.1021/ie50607a031

${ }^{20}$ M. Modesti, A. Lorenzeti, Eur. Polym. J., 37 (2001), 949-954, doi:10.1016/S0014-3057(00)00209-3

${ }^{21}$ J. L. Han, C. H. Yu, Y. H. Lin, K. H. Hsieh, J. Appl. Polym. Sci., 107 (2008) 6, 3891-3902, doi:10.1002/app.27421

${ }^{22}$ J. T. Vanderberg, An Infrared Spectroscopy Atlas for the Coating Industry, Federation of Societies for Coatings Technology, Chicago 1980

${ }^{23}$ B. A. Hess, L. J. Schaad, P. Carsky, R. B. Zahradnik, Chem. Rev., 86 (1986) 4, 709-730, doi:10.1021/cr00074a004

${ }^{24}$ O. Levenspiel, Chemical reaction engineering, Wiley, New York 1972

${ }^{25}$ International Standard ISO22412 - Particle Size Analysis: Dynamic Light Scattering, International Organization for Standardization, 2008

${ }^{26}$ P. Krol, B. Krol, R. Stagraczynski, K. Skrzypiec, J. Appl. Polym. Sci., 127 (2013), 2508-2519, doi:10.1002/app.37552

${ }^{27}$ K. Bagdi, K. Molnar, B. Pukanszky Jr., B. Pukanszky, J. Therm. Anal. Calorim., 98 (2009), 825-832, doi:10.1007/s10973-009-0528-z

${ }^{28}$ E. A. Collins, Measurement of Particle Size and Particle Size Distribution, In. P. A. Lovell, M. S. El-Aasser (Eds.), Emulsion Polymerization and Emulsion Polymers, John Wiley and Sons, Chichester 1997 